\title{
Physical fitness of amateur paddle tennis players: comparisons between different competitive levels
}

\author{
Camila Borges Müller ${ }^{1 *}$, Fabricio Boscolo Del Vecchio ${ }^{1}$
}

ORIGINAL ARTICLE

\begin{abstract}
Paddle tennis is widely practiced racket sport, although there is scanty data comparing competitive levels and differences between the sexes. Physical fitness of paddle tennis players was compared, according to sex and level. The research involved 35 people (age $=29.6 \pm 2.9$ years, practice $=6.8 \pm 4.9$ years), 13 of the first, 15 of the second and 7 of the third category. Traveled distance with Yo-Yo IR1 (YOYOIR1), agility with handball agility specific test (HAST), vertical jump height (VJ) and $3 \mathrm{~kg}$ medicine ball throwing distance (MBT), and handgrip endurance strength (HES) with dynamometer were measured. The variables YOYOIR1, HAST, VJ, MBT and FIPM were statistically different between sexes. In addition, in the male category, players in the first category had lower heart rate scores after YOYOIR1 as well as distance traveled, throttle and FIPM maximum, while in females the superior category was better in the variables in YOYOIR1 $(293 \pm 54 \mathrm{~m})$ and VJ $(28,4 \pm 5,3 \mathrm{~cm})$. On the other hand, in both sexes, players of superior categories presented greater time of practice. Amateur paddle tennis players with a higher competitive level do not present higher physical fitness, but present longer practice time.

Keywords: racquet sports, physical effort, athletic performance.
\end{abstract}

\section{INTRODUCTION}

Paddle tennis is an intermittent racket sport (Castillo-Rodríguez, Hernández-Mendo \& Alvero-Cruz, 2014) and it is characterized by repeated short sprints, with brief recovery periods (Castillo-Rodríguez, 2011). The paddle tennis game intensity is similar to the tennis practice (Hoyo, Sañudo, \& Carrasco, 2007), with mean oxygen uptake $\left(\mathrm{VO}_{2}\right)$ during the game less than $50 \%$ of maximum oxygen uptake $\left(\mathrm{VO}_{2 \max }\right)$ obtained in incremental treadmill test. In games, about mean cardiac demands are near from $75 \%$ of the maximal heart rate $\left(\mathrm{HR}_{\max }\right)$ (Hoyo et al., 2007), but there are variations with values reaching $190 \mathrm{bpm}$ in high intensity actions and $120 \mathrm{bpm}$ in recovery intervals (Sánchez-Alcaraz, 2014). In paddle tennis players, no significant increase in blood lactate concentration was observed from the beginning to the end of a match $(1.9 \pm 0.6$ and $2.88 \pm 1.3 \mathrm{mmol} / \mathrm{l}$, respectively), indicating low glycolytic participation during practice (Amieba \& Salinero, 2013). Despite the low number of studies related to paddle tennis, it seems that physical fitness may contribute to the game, and athletes from higher competitive level could exhibit differences in physical fitness when compared to lower level players (Novas, Rowbottom \& Jenkins, 2003; Sánchez-Alcaraz, 2014). However, there is no information available on comparisons between competitive levels and between sexes in the sport, and these data could contribute to the training organization.

The playing time in paddle tennis tends to be shorter than the rest time, and the average duration of the activities that generate points is, approximately, 11,62 s for men and 18,65 s for women (Sánchez-Alcaraz, 2014). In addition, it was observed that the effective playing time corresponds to $45,92 \%$ of the total game time (García, Bartolomé, Díaz, Muñoz, \& Muñoz, 2014). In this context, among the physical fitness components, a previous study indicates that body composition is determinant for racket sports players performance, and paddle tennis players have a mean of $18.3 \pm 6.2 \%$ of body fat (Martinez-Rodriguez, Collado \& Vicente-Salar, 2015). It is important to point that the ability to

\footnotetext{
$\overline{\text { Manuscript received at June } 2^{\text {nd }} 2018 \text {; Accepted }}$ at November $14^{\text {th }} 2018$

${ }^{1}$ Federal University of Pelotas, Pelotas, Brazil

* Corresponding author: R. Gomes Carneiro, 1 - Centro, Pelotas - RS, 96010-610, Brasil

Email: camila_sls_@hotmail.com
} 
produce muscular strength at high speed is essential for racket sports and anaerobic power is required in highly explosive movements (Groppel \& Roetert, 1992). For the paddle tennis match, the handgrip isometric strength is also relevant, especially to execute successive actions holding the racket (Zanchet \& Del Vecchio, 2013), and has been associated with a greater chance of success in some sports modalities (BonitchGóngora \& Almeida, 2014). From the aerobic point of view, the game intensity is close to the demand of individual tennis, as well as the $\mathrm{VO}_{2}$ of players from both sports is similar in both maximum $\left(55.64 \pm 8.84 \mathrm{ml}^{-1} \mathrm{~kg}^{-1} \cdot \mathrm{min}\right)$ and mean values during the game (Hoyo et al, 2007). However, the actual physical requirements during matches are different, due to the shorter distance covered by the paddle tennis player and greater number of actions in individual tennis (Hoyo et al, 2007). As in tennis (Kovacs, 2007), paddle tennis requires efforts characterized by quick starts, braking and repeated strokes ranging from moderate to sub-maximal intensities (Amieba \& Salinero, 2013). Additionally, in Brazil, competitors are organized into five categories in both sexes, due to competitive success.

Practitioners of racket sports need to know and develop their physical abilities in order to increase the competitive level (Sánchez-Alcaraz, 2014). Due to the growth of paddle tennis in the last years, the analysis of physical aspects is relevant to improve the players' training programs (Hoyo et al., 2007). In addition, new studies are needed to explore field tests that are adequate to the modality (Priego Quesada et al., 2013). Still, despite the paddle tennis' popularity in some countries and athletes' performance is developing, the scientific literature on this sport is rather scarce (Castillo-Rodríguez et al., 2014), which reflects less information for the design of more effective interventions. It should be emphasized that sports performance in the paddle tennis could be determined by physical aspects, specific skills and competitive strategies (Amieba \& Salinero, 2013), and it is relevant to investigate the physical performance of its athletes. Considering that in different modalities the competitive level differs by tactical-technical and physical aspects, this investigation expected better performance in physical fitness tests in individuals of higher categories. Thus, the aim of the present study was to compare and correlate the physical fitness of male and female players from different competitive paddle tennis categories.

\section{METHOD}

\section{Participants}

This is a cross-sectional observational study involving paddle tennis players from different categories. For the sample recruitment process, during the first half of 2015 all participants of paddle tennis competitions in the southern region of Rio Grande do Sul, Brazil, were invited. They should be willing to participate in data collection during the second half of 2015, be a regular practitioner of the sport (twice or more per week), with 24 to 35 years old. Sports injuries, cadiometabolic problems or locomotor injuries that did not allow maximum efforts were assumed as exclusion criteria. After successive publicity efforts at the events and contact with practice centers in the city of Pelotas, the final sample consisted of 35 players from the first, second and third male categories and first and second female categories. Seven men in each male category, six women in the first category and eight women in the second category were included. To participate in the sample, individuals should read and sign a free and informed consent form, and the research project was approved by the local ethics committee (Protocol number 008/2011).

\section{Measures}

The physical fitness components were evaluated for upper and lower limbs power, handgrip endurance, agility, and aerobic fitness. Upper limbs power was evaluated by $3 \mathrm{~kg}$ medicine ball throwing (Silva, Penido, Junior, Souza, \& Villaverde, 2014), lower limbs power by Squat Jump (Markovic, Dizdar, Jukic, \& Cardinale, 2004) with a contact mat (Jump System, CEFISE ${ }^{\circledR}, \quad$ Nova Odessa, Brazil), handgrip endurance strength hold from a validated protocol with hidraulic dynamometer (Bonitch-Góngora, Almeida, Padial, Bonitch- 
Domínguez, \& Feriche, 2013), agility by Handball Agility Specific Test (Iacono, Eliakim, \& Meckel, 2015) registered by photocells (MultiSprint Full Kit, HidroFit ${ }^{\circledR}$, Belo Horizonte, Brazil) and aerobic fitness by Yo-Yo Intermittente Recovery Test Level 1 in a multi-sport court (Krustrup et al., 2003).The routines were conducted by two previously trained evaluators, under continuous and proximal supervision, realized in a single session.

\section{Procedures}

For evaluation, the subjects were advised to did not perform physical exercises $24 \mathrm{~h}$ before the data collection. The nutritional habits and caffeine ingestion were not controlled; however, the subjects did not eat food for at least 2 hours before to the evaluation. The data collection were performed between 3 p.m. and 6 p.m. on a parquet court and temperature between $22^{\circ}$ and $28^{\circ} \mathrm{C}$. Prior to application, subjects were adequately familiarized with the tests.

Firstly, the Yo-Yo Intermittent Recovery Test Level 1 (YOYOIR1) was used to evaluate the aerobic fitness, and it consists of $20 \mathrm{~m}$ displacements with speed controlled by beeps from an audio tape. Between each bout of $20 \mathrm{~m}$ there is a recovery of 10 seconds (Krustrup et al., 2003). When the person was unable to cover the $20 \mathrm{~m}$ twice, the test was finished and the whole distance covered was registered (Krustrup et al., 2003). The test was performed in a sport's court marked by cones, being $2 \mathrm{~m}$ wide and $20 \mathrm{~m}$ long, and a cone marking the active recovery space was placed $5 \mathrm{~m}$ from the finish line (Krustrup et al., 2003). The subjects were familiarized with an immediate pre-test, and the relative $\mathrm{VO}_{2 \max }$ was estimated with the equation: $\mathrm{VO}_{2 \max }\left(\mathrm{ml}^{-1} \cdot \mathrm{kg}\right.$ $\left.{ }^{1} \cdot \min \right)=$ distance $(\mathrm{m}) \times 0.0084+36.4$ (Bangsbo, Iaia, \& Krustrup, 2008). Heart rate (HR) values were recorded before and after with cardiofrequencimeters (POLAR ${ }^{\mathrm{TM}}$ RS800CX). The final HR was considered as maximal HR $\left(\mathrm{HR}_{\max }\right)$, and previous data indicate that this HR value tends to be similar in $99-100 \%$ when compared to the treadmill test, besides showing correlation coefficient test-retest of 0.99 and coefficient of variation of $8.5 \%$ (Krustrup et al., 2003).
Agility was measured by the Handball Agility Specific Test (HAST), which was chosen because it exhibited five changes of direction at short distances, and included back and forth races, as well as lateral displacements (Iacono et al., 2015), which were very frequent in paddle tennis. For its realization, subject starts from cone 1 and runs in a straight line from $5 \mathrm{~m}$ to cone 2 , where it carries out lateral displacement of $3.5 \mathrm{~m}$ to cone 3 , again moves laterally $3.5 \mathrm{~m}$ to the cone 4 , runs from the back $5 \mathrm{~m}$ to the cone 5 , carries out the lateral displacement of $3.5 \mathrm{~m}$ to the cone 3 and finally moves laterally by $3.5 \mathrm{~m}$ to the cone 1 . Two attempts have been made, with five minutes of interval between them, and the faster attempt was recorded as valid (Iacono et al., 2015). The timing was registered from photocells arranged in the first cone. The intra-class correlation coefficient of the HAST described is 0.92 and the typical measurement error of $2.3 \%$ (Iacono et al., 2015).

Squat Jump (SJ) was used to evaluate lower limbs power, and the procedures were performed on a contact mat. Subjects performed three vertical jump attempts with hands at the waist, maintaining initial position with $90^{\circ}$ knee flexion, evaluated with a goniometer. Then, after three seconds in the described position, the individuals performed triple extension, propelling themselves in the highest speed and force possible, and during the flight phase the knees should be fully extended (Markovic et al., 2004). Three trials were carried out with a five-minute interval between them and the best was considered. SJ exhibits Cronbach's alpha of 0.97, with a coefficient of variation of $2.4 \%$ to $4.6 \%$ (Markovic et al., 2004).

The upper limbs power was evaluated through Medicine Ball Throwing (MBT), which was performed with the dominant hand, with the participant sitting in a chair leaning against a wall with his feet on the ground (Silva et al., 2014). The subjects positioned themselves with the trunk resting on the back of the chair held by a strip below the chest. The $3 \mathrm{~kg}$ medicine ball was held by the subject with a $90^{\circ}$ elbow flexion and abduction and then thrown as far as possible over an inextensible demarcation (Silva et al., 2014). The performance was evaluated by the distance in 
meters between the front feet of the chair and the first contact of the ball on the ground. Three trials were performed with a three minutes interval between them and the mean value for the final result of the test, which showed a statistically significant correlation of $0,73(\mathrm{p}<0,001)$ with power produced in isokinetic dynamometry at $180 \%$ s (Silva et al., 2014).

The test used for handgrip endurance strength (HES) measurement consists of eight 10-s maximum isometric contractions with a passive interval of 10 seconds, which is sensitive to detect differences between different competitive levels (Bonitch-Góngora et al., 2013). The subject sited in a chair with the back supported and feet on the floor, with neutral shoulder adduction and rotation, $90^{\circ}$ elbow flexion, forearm in neutral position and extended wrist between 0 and $30^{\circ}$, with an ulnar deviation between 0 and $15^{\circ}$. The subjects were instructed to apply the highest strength during each repetition (BonitchGóngora, Almeida, Padial, Bonitch-Domínguez, \& Feriche, 2013), and the highest value of each contraction was recorded. Although the psychometric characteristics of the validation of the test were not localized, it closely resembles the paddle tennis demands. The highest value of eight measures of HES was considered as the maximum $\left(\mathrm{HES}_{\max }\right)$, the lowest value was assumed as the minimum (HES $\mathrm{Hin}_{\text {min }}$ ), as well as the mean $\left(\mathrm{HES}_{\mathrm{med}}\right)$ and the index of fatigue $\left(\mathrm{HES}_{\mathrm{fatigue}}\right.$, in \%).

\section{Statistical analysis}

In statistical analysis, normality verification was checked by Shapiro-Wilk test. Data are presented as mean and standard deviation and, after testing the homogeneity of variances with Levene test, comparisons between sex and level were performed with two-way analysis of variance (sex $\mathrm{x}$ category). When significant differences were observed, Tukey post-hoc was used to locate them. Comparisons of the values of $\mathrm{HR}_{\max }$ obtained directly versus age-predicted (220-age, TANAKA, HUNT-generic or HUNT-age; Nes, Janszky, Wisloff, Stoylen, \& Karlsen, 2013) were performed with t-test for paired samples, and the $95 \%$ confidence intervals of differences IC 95\% (dif) are given in bpm. Correlations were performed using the Pearson test. 5\% was assumed as the level of statistical significance and in analyzes of variance the value of partial square eta $\left(\eta^{2}\right)$ was presented. The analysis routines were performed in SPSS, version 20.0 .

Table 1

Descriptive measures of age, practice time and physical performance of amateur paddle players, according to sex and competitive level $(N=35)$

\begin{tabular}{|c|c|c|c|c|c|c|c|c|}
\hline & \multicolumn{4}{|c|}{ Men } & \multicolumn{3}{|c|}{ Women } & \multirow{2}{*}{$\begin{array}{l}\text { All group } \\
(\mathrm{N}=35)\end{array}$} \\
\hline & $1(n=7)$ & $2(n=7)$ & $3(n=7)$ & All $(n=21)$ & $1(n=6)$ & $2(n=8)$ & All $(n=14)$ & \\
\hline Age (years) & $30.0 \pm 4.0$ & $30.6 \pm 2.3$ & $29.1 \pm 3.6$ & $29.9 \pm 3.2$ & $28.8 \pm 3.3$ & $29.6 \pm 2.1$ & $29.3 \pm 2.6$ & $29.7 \pm 3.0$ \\
\hline Practice (years) & $13.3 \pm 5.3^{2.3}$ & $6.0 \pm 2.0$ & $3.9 \pm 3.7$ & $7.7 \pm 5.6$ & $6.8 \pm 5.0^{2}$ & $4.8 \pm 2.6$ & $5.6 \pm 3.8$ & $6.9 \pm 5.0$ \\
\hline YOYOIR1 & & & & & & & & \\
\hline HR pre (bpm) & $80.6 \pm 10.9$ & $98.6 \pm 14.9^{3}$ & $81.7 \pm 7.5$ & $87.0 \pm 13.8$ & $93.8 \pm 14.1$ & $96.5 \pm 11.2$ & $95.4 \pm 12.1$ & $90.3 \pm 13.6$ \\
\hline HR post (bpm) & $171.3 \pm 9.6^{2}$ & $182.9 \pm 7.6$ & $181.4 \pm 9.2$ & $178.5 \pm 9.9$ & $175.7 \pm 7.2^{2}$ & $183.0 \pm 9.7$ & $179.9 \pm 9.2$ & $179.1 \pm 9.5$ \\
\hline Distance $(\mathrm{m})^{*}$ & $308 \pm 82^{3}$ & $480 \pm 128^{3}$ & $485 \pm 178$ & $424 \pm 153$ & $293 \pm 54^{2}$ & $190 \pm 66$ & $234 \pm 79$ & $348 \pm 159$ \\
\hline $\operatorname{HAST}(\mathrm{s})^{*}$ & $8.3 \pm 0.6$ & $7.9 \pm 0.4$ & $8.3 \pm 0.7$ & $8.2 \pm 0.6$ & $8.8 \pm 0.6$ & $9.8 \pm 0.7$ & $9.4 \pm 0.8$ & $8.7 \pm 0.9$ \\
\hline $\mathrm{VJ}(\mathrm{cm})^{*}$ & $33.6 \pm 4.8$ & $36.2 \pm 3.2$ & $34.0 \pm 5.9^{2}$ & $34.6 \pm 4.7$ & $28.4 \pm 5.3^{2}$ & $20.5 \pm 4.6$ & $23.9 \pm 6.2$ & $30.3 \pm 7.5$ \\
\hline $\operatorname{MBT}(\mathrm{m})^{*}$ & $4.1 \pm 0.8^{2.3}$ & $4.6 \pm 0.4^{3}$ & $4.8 \pm 1.1$ & $4.5 \pm 0.8$ & $3.0 \pm 0.3$ & $2.7 \pm 0.2$ & $2.8 \pm 0.3$ & $3.8 \pm 1.1$ \\
\hline $\mathrm{HES}_{\max }(\mathrm{kgf})^{*}$ & $46.3 \pm 11.7^{2.3}$ & $51.6 \pm 5.4^{3}$ & $49.0 \pm 6.0$ & $49.0 \pm 8.1$ & $30.3 \pm 2.7$ & $29.6 \pm 4.3$ & $29.9 \pm 3.6$ & $41.3 \pm 11.5$ \\
\hline $\mathrm{HES}_{\min }(\mathrm{kgf})^{*}$ & $31.3 \pm 8.0$ & $32.6 \pm 4.2$ & $29.9 \pm 3.2$ & $31.2 \pm 5.4$ & $23.0 \pm 2.7$ & $19.9 \pm 3.9$ & $21.2 \pm 3.7$ & $27.2 \pm 6.8$ \\
\hline $\mathrm{HES}_{\mathrm{med}}(\mathrm{kgf})^{*}$ & $37.2 \pm 9.1$ & $39.1 \pm 4.0$ & $37.2 \pm 4.0$ & $37.8 \pm 5.9$ & $26.7 \pm 2.1$ & $23.2 \pm 3.8$ & $24.7 \pm 3.6$ & $32.6 \pm 8.3$ \\
\hline HES $_{\text {fatigue }}(\%)$ & $31.7 \pm 13.1$ & $36.1 \pm 11.7$ & $38.5 \pm 7.9$ & $35.4 \pm 10.9$ & $24.3 \pm 4.6$ & $33.1 \pm 5.7$ & $29.3 \pm 6.8$ & $33.0 \pm 9.9$ \\
\hline
\end{tabular}




\section{RESULTS}

The group had $29.7 \pm 3$ years old, with no differences between sexes $\left(\mathrm{F}=0.80 ; p=0.38 ; \eta^{2} \mathrm{p}\right.$ $=0.02)$ or categories $\left(\mathrm{F}=0.48 ; p=0.61 ; \eta^{2}{ }_{\mathrm{p}}=\right.$ 0.03 ), and $6.9 \pm 5$ years of practice, with a longer time of exposure $\left(\mathrm{F}=6.9 ; p=0.01 ; \mathrm{\eta}_{\mathrm{p}}^{2}=0.19\right)$, and with differences between categories $(\mathrm{F}=$ $\left.10.35 ; p<0.001 ; \eta^{2}=0.41\right)$. Of the entire sample $(\mathrm{N}=35)$, only two men were left-handed, one in the $1^{\text {st }}$ category and the other in the $2^{\text {nd }}$ category. The data related to the execution time and the effectiveness of the physical tests are presented in table 1.

The multivariate statistical analysis revealed significant differences between sexes $(\mathrm{F}=10.61$; $\left.p<0.001 ; \eta^{2} \mathrm{p}=0.87\right)$, categories $(\mathrm{F}=2.43 ; p=$ $\left.0.006 ; \eta_{\mathrm{p}}^{2}=0.59\right)$ and significant interactions between sex and category $(\mathrm{F}=4.03 ; p=0.003$; $\left.\eta_{\mathrm{p}}^{2}=0.72\right)$. Sex differences were identified in YoYo IRL1-related variables $(\mathrm{F}=12.89 ; \mathrm{p}=0.01$; $\left.\eta_{p}^{2}=0.30\right)$, HAST agility tests $(\mathrm{F}=26.98 ; p<$ $\left.0.001 ; \mathrm{\eta}^{2} \mathrm{p}=0.47\right)$, SJ $\left(\mathrm{F}=32.87 ; p<0.001 ; \mathrm{\eta}^{2}{ }_{\mathrm{p}}\right.$ $=0.52)$, MBT $\left(\mathrm{F}=36.73 ; p<0.001 ; \eta_{\mathrm{p}}^{2}=0.55\right)$; $\mathrm{HES}_{\max }\left(\mathrm{F}=53.98 ; p<0.001 ; \eta_{\mathrm{p}}^{2}=0.64\right), \mathrm{HES}_{\min }$ $\left(\mathrm{F}=33.11, p<0.001, \eta_{\mathrm{p}}^{2}=0.52\right)$ and $\mathrm{HES}_{\mathrm{med}}(\mathrm{F}$ $\left.=44.57 ; p<0.001 ; \eta_{\mathrm{p}}^{2}=0.60\right)$, but not in $\mathrm{HES}_{\text {fatigue }}\left(\mathrm{F}=2.20, p=0.15 ; \eta_{\mathrm{p}}^{2}=0.07\right)$. Among the categories, differences were found only in the HR pre and post YoYo IRL1 (respectively $\mathrm{F}=$ 3.61; $p=0.04 ; \eta_{\mathrm{p}}^{2}=0.19$ and $\mathrm{F}=4.57 ; p=0.02$; $\left.\eta_{p}^{2}=0.23\right)$. Finally, significant interactions were

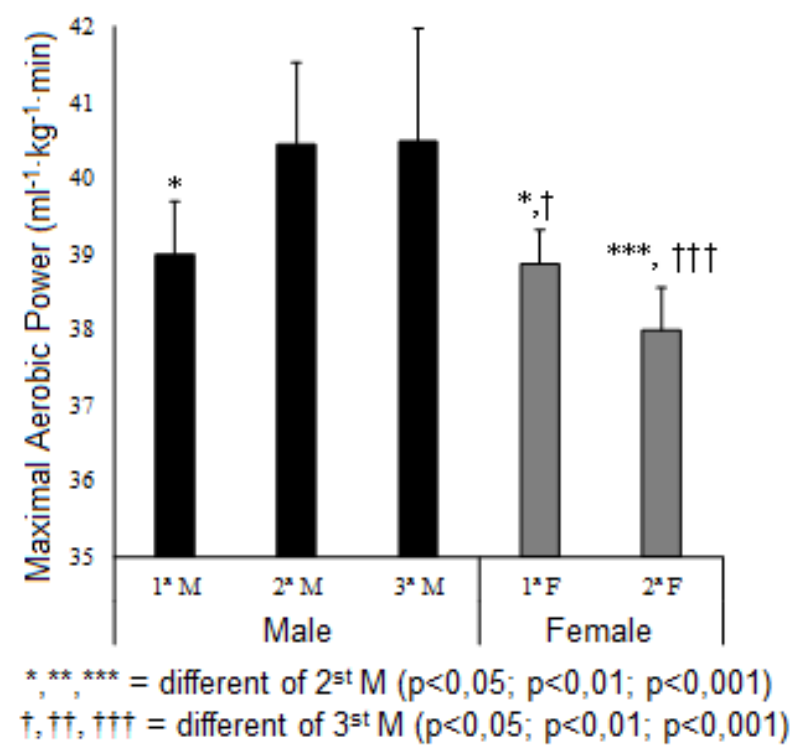

identified in the variables associated with YoYo IRL1 $\left(\mathrm{F}=10.43 ; p=0.003 ; \eta^{2}{ }_{\mathrm{p}}=0.26\right)$; HAST $\left(\mathrm{F}=7.9 ; p=0.009 ; \eta^{2}=0.21\right)$ and $\mathrm{SJ}(\mathrm{F}=8.14$; $\left.p=0.008 ; \eta^{2} \mathrm{p}=0.21\right)$, which are shown in table 1.

The estimated $\mathrm{VO}_{2 \max }$ for men was $40.0 \pm 1.3$ $\mathrm{mL}^{-1} \cdot \mathrm{Kg}^{-1} \cdot \mathrm{min}$ and $38.4 \pm 0.7 \mathrm{~mL}^{-1} \cdot \mathrm{Kg}^{-1} \cdot \mathrm{min}$ for women, with significant differences between sexes $\left(F=11.38 ; p<0.001 ; \eta^{2}=0.30\right)$. However, no differences were found between categories $\left(\mathrm{F}=1.8 ; p=0.17 ; \eta_{\mathrm{p}}^{2}=0.11\right)$, but were identified interactions between sex and category $\left(\mathrm{F}=10.4 ; p=0.003 ; \eta_{\mathrm{p}}^{2}=0.26\right)$. The third category was different from the $1^{\text {st }}(p=$ $0.004)$ and $2^{\text {nd }}(p=0.01)$, which are presented in figure 1 (panel A). Regarding the $\mathrm{HR}_{\max }$ obtained in Yo-Yo IRL1 (figure 1, panel B), statistically significant differences were observed when compared to the prediction using 220-age $(\mathrm{t}=$ 7.08; $p<0.001 ; 95 \% \mathrm{CI}=8-14 \mathrm{bpm})$, TANAKA equation ( $\mathrm{t}=5.17 ; p<0.001 ;$ CI95\% dif $=5-11$ $\mathrm{bpm})$, and general ( $\mathrm{t}=8.2 ; p<0.001$; $\mathrm{CI} 95 \%=$ 10-16 bpm) and sex-specific equations $(\mathrm{t}=8.6 ; p$ $<0.001$; CI95\% = 10-17 bpm) from the HUNT study (figure 2). There were no significant correlations between the four procedures (220-age: $\mathrm{r}=0.18 ; \mathrm{p}=0.28$; TANAKA: $\mathrm{r}=$ $0.18 ; \mathrm{p}=0.29 ;$ HUNT general: $\mathrm{r}=0.18 ; \mathrm{p}=0.28$ and HUNT considering sexes: $\mathrm{r}=0.14 ; \mathrm{p}=0.43$ ) (Nes, Janszky, Wisloff, Stoylen, \& Karlsen, 2013).

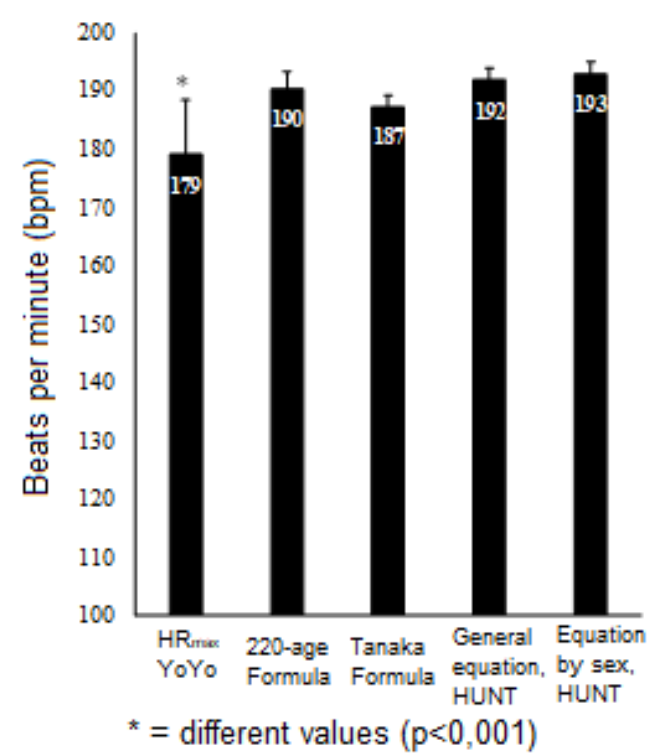

Figure 1. Estimated maximum oxygen consumption and maximum heart rate values in paddle players $(\mathrm{N}=35)$ 
Bivariate correlations were tested, which were controlled by sex and competitive category due to significant differences previously presented. Significant values of the $\mathrm{HR}_{\max }$ in the Yo-Yo IR L1 test with distance in the same test $(\mathrm{r}=0.50 ; p=$ $0.003)$, performance in the HAST agility test $(r=$ $-0.47 ; p=0.006)$ and $\mathrm{HES}_{\text {fatigue }}$ index $(\mathrm{r}=0.34$; $p=0.05)$. The distance in YOYOIR 1 correlated negatively with performance in the HAST $(r=$ $-0.46 ; p=0.006)$ and in a positive way with height in the $\mathrm{SJ}(\mathrm{r}=0.57 ; p=0.001)$. Agility in HAST correlated negatively with the upper limbs power in MBT $(\mathrm{r}=-0,44 ; p=0.01), \mathrm{HES}_{\max }(\mathrm{r}$ $=-0.48 ; p=0.005)$, HES $_{\text {med }}(\mathrm{r}=-0.39 ; p=$ $0.02)$ and $\mathrm{SJ}(\mathrm{r}=-0.76 ; p<0.001)$. The height in SJ, in turn, correlated with the upper limbs power in MBT $(\mathrm{r}=0.57 ; p=0.001), \mathrm{HES}_{\max }(\mathrm{r}=$ $0.45 ; p=0.009)$, $\mathrm{HES}_{\min }(\mathrm{r}=0.41 ; p=0.02)$ and HES $_{\text {med }}(\mathrm{r}=0.50 ; p=0.003)$. Finally, MBTshowed significant correlations with $\mathrm{HES}_{\max }$ $(\mathrm{r}=0.53 ; \mathrm{p}=0.001)$, RHIS $(\mathrm{r}=0.56 ; \mathrm{p}=0.001)$ and $\mathrm{HES}_{\mathrm{med}}(\mathrm{r}=0.66 ; p<0.001)$. The data of the correlations of interest, by sex, are presented in figure 2 .
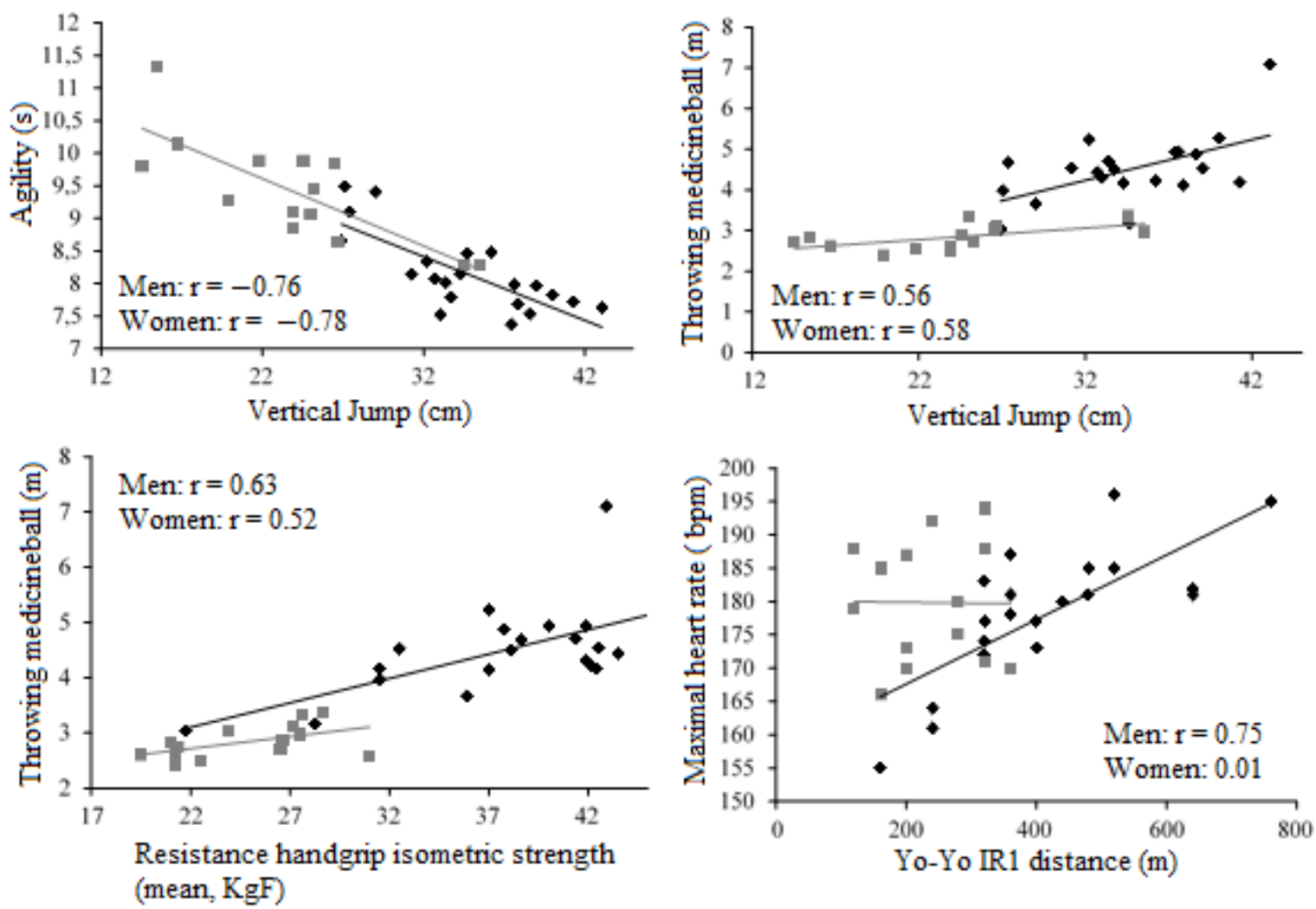

Figure 2. Bivariate correlations, by sex (women = gray squares, men = black lozenges)

\section{DISCUSSION}

The present study aimed to evaluate and compare the physical fitness level of amateur paddle tennis players. The main findings were: i) sex differences in YOYOIR1, HAST, SJ, MBT, as well as in the HES and ii) absence of statistically superior values in the categories of higher competitive level, being that among men, category 2 and/or 3 athletes were better than those of category 1 in the YOYOIR1, MBT and HES tests.
It is indicated that the aerobic fitness was not statistically different between categories, and this can be explained because this variable, perhaps, does not determine amateur success in paddle tennis. Furthermore, it was observed that, in addition to the technical level, the time of practice could be associated with higher categories than the cardiorespiratory fitness level. However, it is pointed out that high aerobic power can be beneficial because it delays the fatigue appearance in of high intensity moments (Nakamura, Brunetto, Hirai, Roseguini \& 
Kokubun, 2005), which could be important in the paddle tennis, since the intermittent demand should be maintained during the whole time of the match (Amieba e Salinero, 2013). Elite tennis players have $\mathrm{VO}_{2 \max }$ values greater than $50 \mathrm{ml}^{-}$ ${ }^{1} \cdot \mathrm{kg}^{-1} \cdot \mathrm{min}$ in males and $42 \mathrm{ml}^{-1} \cdot \mathrm{kg}^{-1} \cdot \mathrm{min}$ in females (Kovacs, 2007). In young players of the 2008 Brazilian badminton team $($ women $=15.2$ \pm 2.06 years old and men $=17.2 \pm 1.2$ years old) $\mathrm{VO}_{2 \max }$ was also evaluated through Yo-Yo IR1, and women reached $43.23 \pm 2.98 \mathrm{ml}^{-1} \cdot \mathrm{kg}^{-1} \cdot \mathrm{min}$ and the men reached $50.15 \pm 2.51 \mathrm{ml}^{-1} \cdot \mathrm{kg}^{-1} \cdot \mathrm{min}$ (Durigan, Dourado, \& Stanganelli, 2013). Among young Spanish paddle tennis players (16.57 \pm 1,51 years old), $\mathrm{VO}_{2 \max }$ values of $55.64 \pm 8.84 \mathrm{ml}^{-}$ ${ }^{1} \cdot \mathrm{kg}^{-1} \cdot \mathrm{min}$ were found in incremental treadmill test, and maximum heart rate of $200.43 \pm 15.76$ bpm (Hoyo et al., 2007). In the incremental maximal treadmill test, elite female paddle tennis athletes $\left(28.2 \pm 0.6\right.$ years old) achieved a $\mathrm{VO}_{2 \max }$ of $47 \pm 33 \mathrm{ml}^{-1} \cdot \mathrm{kg}^{-1} \cdot \min$ (Fuente et al., 2014), higher than the observed in the present study. In the present study, the use of Yo-Yo IR1 was chosen because it presented intermittent characteristics and could be performed on a court, similar to the requirements of the padle tennis game (Castillo-Rodríguez et al., 2014). In this sense, the mean values of $\mathrm{VO}_{2 \max }$ were lower than those found in the literature, probably because the sample was composed of recreational and non-professionalprofile of our sample. The absence of significant differences between categories may be due to the fact that aerobic fitness is not determinant for sports success in paddle tennis, at least when played at regional level. The $\mathrm{HR}_{\max }$ values obtained in the present study were statistically lower than those calculated by predictive equations (Nes et al., 2013). Probably for the following reasons: (i) peripheral fatigue may have caused early withdrawal of the YOYOIR1 test; (ii) the participants were not accustomed to such long and successive linear races $(20 \mathrm{~m}+20 \mathrm{~m})$ despite its intermittent routine; and (iii) athletes did not exercise until their maximum capacity. However, the third item can be discarded due to the sample's dedication and involvement, which would increase the probability of having happened the first one. Complementarily, the paddle tennis court is 20 meters by 10 meters, which also reinforces the possibility of not adjusting the YOYOIR 1 of $20 \mathrm{~m}+20 \mathrm{~m}$ for this racket modality (Bangsbo et al., 2008).

In agreement with the well-developed aerobic component, paddle tennis practitioners need agility, which is a very relevant variable for adequate movement and correct positioning in the court (Groppel \& Roetert, 1992). Agility is required, especially during acceleration, deceleration and displacement (Amieba \& Salinero, 2013; Durigan et al., 2013). In the present study, it was decided to employ HAST, since it involves paddle tennis-like displacements such as pull out and rapid braking, with successive changes of direction (Amieba \& Salinero, 2013). In this context, Iacono et al. (2015) evaluated elite handball players, and found better values $(6.72 \pm 0.22 \mathrm{~s})$ than those of amateur players in this study $(8.2 \pm 0.6 \mathrm{~s}$ for men and $9.4 \pm 0.8 \mathrm{~s}$ for women). However, we reinforced the need for additional strategies to assess agility, including the use of racket.

In paddle tennis, some gestures require repeated and frequent use of hand grip strength, as in subsequent volleys (Zanchet \& Del Vecchio, 2013). A previous study with paddle tennis athletes, it was found $\mathrm{HES}_{\max }$ of $40.41 \pm 10.98$ kgf (Zanchet \& Del Vecchio, 2013), similar to the results obtained in the present study $(41.3 \pm 11.5$ kgf) for the higher effort performed within a series of eight successive actions of 10s each, with 10 s intervals. Currently, there are two more frequent procedures for evaluating isometric handgrip strength. The first uses a maximum isometric handgrip strength percentage, such as $70 \%$ of this value, and records the time in which the assessed person can maintain continuously the determined value. This was done previously with tennis players and values of $33.46 \pm 10.45$ seconds were found (Zanchet \& Del Vecchio, 2013). In contrast, maintaining maximum percentage values does not seem to be the best strategy for assessing strength endurance in racket sports, given the intermittent nature of practice and racket strokes. Thus, in the present study, successive contractions were performed, which appear to be more suited to the sport's specificity (Bonitch-Góngora et al., 2013). In 
addition, in the present study, the fatigue index was evaluated and, although there were differences between the sexes for HES, with higher values among men, the fatigue rate was similar to that of women, with a $33 \pm 9.9 \%$ fall in the whole group.

The lower limbs power is important in the paddle tennis, as the strength transfers the reaction force from the ground to the trunk and generates greater power in some blows (Girard, Micallef, \& Millet, 2005). In addition, power is relevant to perform multiple changes of direction and efficient strokes with the racket (SánchezAlcaraz \& Sánchez-Pay, 2010). In the present study, in addition to men performing better than women, second-category male players presented higher values than those of the third category, but were not inferior to those of the first ones. On the other hand, the first category women practitioners exhibited higher values than those of the second category. In general, there are no significant differences in the jump against movement among beginning, intermediate and elite tennis players (Girard et al., 2005). A study of elite and sub-elite badminton players found squat jump values of $42.7 \pm 5.2$ and $41.5 \pm 5.2$ $\mathrm{cm}$, respectively (Ooi et al., 2009). Professional male and female badminton athletes reached $27.20 \pm 2.14 \mathrm{~cm}$ and $36.73 \pm 6.03 \mathrm{~cm}$, respectively (Durigan, Dourado \& Stanganelli, 2013), and were higher than the findings of the present study (men $=34.6 \pm 4.7 \mathrm{~cm}$, women $=$ $23.9 \pm 6.2 \mathrm{~cm}$, whole group $=30.3 \pm 7.5 \mathrm{~cm}$ ); however, the present investigation corroborates a study that involved different levels of tennis (Girard et al., 2005), indicating that there were no differences in the lower limbs power between categories.

Due to the need to apply strokes with the racket that cannot be received or countered by opponents in a small play area on the paddle, the upper limbs power could be relevant variable for competitive success (Signorile, Sandler, Smith, Stoutenberg, \& Perry, 2005). However, among amateur level players of the present study, despite differences between sexes, probably due to the technical influence (Shim, Carlton, Chow, \& Chae, 2005), superior performances were not observed among athletes of the higher categories.
Among athletes from Brazilian junior male and female badminton team, aged $17.24 \pm 1.18$ years old and $15.21 \pm 2.06$ years old, respectively, the values were $7.54 \pm 1.01 \mathrm{~m}$ for men, with medicine ball of $3 \mathrm{~kg}$, and $6.98 \pm 0.78 \mathrm{~m}$ for women, with medicine ball of $2 \mathrm{~kg}$ (Campos, Daros, Mastrascusa, Dourado, \& Stanganelli, 2009). These values are also higher than the present study (all $=3.8 \pm 1.1 \mathrm{~m}$, men $=4.8 \mathrm{~m}$ and women $=2.8 \mathrm{~m}$ ), which can be explained by the mass of the implement, difference of competitive level and the age range of the samples.

Regarding the main correlations between variables, it seems that the positive value between $\mathrm{HR}_{\max }$ and distance in the YOYOIR1 among men results from the fact that these male athletes exhibit better physical fitness and, therefore, achieve higher HR until exhaustion in the test (Bangsbo et al., 2008). Data from the present study corroborate Silva et al. (2011), who found a high correlation $(\mathrm{r}=0.71)$ between YoYo IR2 and $\mathrm{HR}_{\max }$ in soccer players. However, as shown in the last panel (figure 3, panel D), the women did not present a significant correlation ( $\mathrm{r}$ $=0.01$ ), and the distance reached by them may have been insufficient to reach $\mathrm{HR}_{\max }$, and this can be explained by the fact that most have never performed maximal aerobic efforts. The relationship between performance in YOYOIRL1 and HAST may result from greater muscle aptitude, given the difference in energy substrates from the tests performed (Hermassi et al., 2014). There was also a significant correlation between HAST and vertical jump, which can be explained by the fact that the shortest time reached in agility tests is related to better performance in the power test, probably due to the similarity in the physical demands for the tests, especially for the elongation-shortening cycle (Picanço, Silva, \& Del Vecchio, 2012).

In this study, physical activity level performed by the subjects was not recorded, so the amount and time of weekly exercise can be considered as a limitation. However, all were regular practitioners of the sport and exceeded 150 minutes per week of physical activity during leisure time. It is also indicated that the tests performed were not very specific for the paddle 
tennis, because no validated tests specific to the modality were found, which provokes new investigations. However, as practical application, these results may be used to identify characteristics of paddle tennis players in different levels.

\section{CONCLUSION}

In conclusion, among these amateur paddle tennis practitioners, it seems that high physical fitness is not a discriminating factor of competitive level. Possibly, players with less physical conditioning compensate this limitation with better technical and tactical development, which, in an amateur context, seems to be enough for the competitive success. This study found lower values of $\mathrm{VO}_{2 \max }$, agility and powerless to those presented in other studies that analyzed elite and professional players, probably due to the amateur nature of the participants. Therefore, future studies can be carried out with paddle tennis players with a higher competitive level (national or continental), for possible comparisons and inferences. Small and few significant differences were found between categories in the analyzed variables, with this, it can be affirmed that in amateur sports such variables do not interfere in the competitive level. Therefore, it is suggested that new investigations involving the categories studied here investigate other variables of the physical fitness that could be determinant for the success in the sport, as well as technical-tactical patterns of the players.

\footnotetext{
Acknowledgments:

The authors are grateful to the subjects who kindly volunteered to participate in this study.
}

Conflict of interests:

Nothing to declare.

\section{Funding:}

Nothing to declare.

\section{REFERENCES}

Amieba, C., \& Salinero, J.J. (2013). Aspectos generales de la competición em pádel y sus demandas fisiológicas. AGON International Journal of Sport Science, 3(2): 60-67.

Bangsbo, J., Iaia, F.M., \& Krustrup, P. (2008). The yoyo intermittent recovery test: a useful tool for evaluation of physical performance in intermittent sports. Sports Medicine, 38: 37-51. doi: 10.2165/00007256-200838010-00004.

Bonitch-Góngora, J.G., \& Almeida, F. (2014). La fuerza isométrica del agarre em judô. Revista de Artes Marciales Asiáticas, 9: 9-19. doi: 10.18002/rama.v9i1.1030.

Bonitch-Góngora, J.G., Almeida, F., Padial, P., BonitchDomínguez, J.G., \& Feriche B. (2013). Maximal isometric handgrip strength and endurance differences between elite and non-elite young judo athletes. Archives of Budo, 4: 239-248.

Campos, F.A.D., Daros, L.B., Mastrascusa, V., Dourado, A.C., \& Stanganelli, L.C.R. (2009). Anthopometric profile and motor performance of junior badminton players. Brazilian Journal of Biomotricity, 3: 146-151.

Castillo-Rodríguez, A. (2011). Evaluación fisiológica através del método de entrenamiento integral em deportistas de pádel de $2^{\mathrm{a}}$ categoria. Comunicación Del Congreso Internacional em Ciencias de La Actividad Física y del Deporte: Investigación, desarrollo $e$ innovación, UPV-EHU.

Castillo-Rodríguez, A., Hernández-Mendo, A., \& Alvero-Cruz, J.R. (2014). Morfología del jugador de élite de pádel - Comparación con otros deportes de raqueta. International Journal of Morphology, 32(1), 177-182. doi: 10.4067/S071795022014000100030.

Durigan, J.Z., Dourado, A.C., \& Stanganelli, L.C.R. (2013). Características antropométricas e de desempenho motor de atletas da seleção brasileira de badminton. Revista Brasileira de Prescrição \& Fisiologia do Exercício, 7: 161-166.

Fuente, F.P., Zagalaz, J.C., Benedí, D.O., Hijós, A.Q., Castellar, S.A.I., \& Otín, C.C. (2014). Análisis antropométrico, fisiológico y temporal em jugadoras de pádel de elite. Retos, 25: 107-112.

García, A., Bartolomé, I., Díaz, J., Muñoz, J., \& Muñoz, D. (2014). Análisis de variables temporales en pádel y surelación com otras variables contextuales. Facultad de Ciencias del Deporte, Universidad de Extremadura. Available in: padelscience.com, number 13.

Girard, O., Micallef, J.P., \& Millet, G.P. (2005). LowerLimb activity during the power serve in tennis: effects of performance level. Medicine $\mathcal{E}$ Science in Sports \& Exercise, 37: 1021-1029. doi: 10.1249/01.mss.0000171619.99391.

Groppel, J.L., \& Roetert, E.P. (1992). Applied physiology of tennis. Sports Medicine, 14(4): 260268. doi: 10.1136/bjsm.2005.023309.

Hermassi, S., Aouadi, R., Khalifa, R., Tillaar, R.V.D., Shephard, R.J., Chelly, M.S. (2014). Relationships between the yo-yo intermittent recovery test and anaerobic performance tests in adolescent handball players. Journal of Human 
Kinetics, 42: 197-205. doi: 10.1515/hukin-20150020197.

Hoyo, M., Sañudo, B., \& Carrasco, L. (2007). Demandas fisiológicas de la competición em pádel. Revista Internacional de Ciencias del Deporte, 3 (8): 53-58. doi: 10.5232/ricyde2007.00805.

Iacono, A.D., Eliakim, A., \& Meckel, Y. (2015). Improving fitness of elite handball players: smallsided games vs. high-intensity intermittent training. Journal of Strength $\mathcal{E}$ Conditioning Research, 29(3): 835-843. doi: 10.1519/JSC.0000000000000686.

Kovacs, M.S. (2007). Tennis physiology: Training the competitive athlete. Sports Medicine, 37: 189-198.

Krustrup, P., Mohr, M., Amstrup, T., Rysgaard, T., Johansen, J., Steensberg, A., ... Bangsbo J. (2003). The yo-yo intermittent recovery test: physiological response, reliability, and validity. Medicine \& Science in Sports \& Exercise, 35(4): 697705.

doi: 10.1249/01.MSS.0000058441.94520.32.

Markovic, G., Dizdar, D., Jukic, I. \& Cardinale, M. (2004). Reliability and factorial validity of squat and countermovement jump tests. Journal of Strength \& Conditioning Research, 18: 551-555. doi: 10.1519/1533-4287.

Martinez-Rodriguez, A., Collado, E.R., \& VicenteSalar, N. (2015). Body composition assessment of paddle and tennis adult male players. Nutricion Hospitalaria, 31: 1294-1301. doi: 10.3305/nh.2015.31.3.8004.

Fábio Yuzo Nakamura, F.Y., Brunetto, A.F., Hirai, D.M., Roseguini, B.T., \& Kokubun, K. (2005). The perceived exertion threshold (PET) corresponds to the critical power and to na indicator of maximal oxygen uptake steady state. Revista Brasileira de Medicina do Esporte, 31(3): 189e-194e. doi: 10.1590/S151786922005000300009.

Nes, B.M., Janszky, I., Wisloff, U., Stoylen, A., \& Karlsen, T. (2013). Age-predicted maximal heart rate in healthy subjects: The HUNT fitness study. Scandinavian Journal of Medicine $\mathcal{E}$ Science in Sports, 23(6): 697-704. doi: 10.1111/j.16000838.2012.01445.x.

Novas, A.M.P., Rowbottom, D.G., \& Jenkins, D.G. (2003). A practical method of estimating energy expenditure during tennis play. Journal of Science E Medicine in Sport, 6: 40-50. doi: 10.1016/S14402440(03)80007-5.

Ooi, C.H. et al. (2009). Physiological characteristics of elite and sub-elite badminton players. Journal of Sports \& Science, 27: 1591-1599. doi: $10.1080 / 02640410903352907$.
Picanço, L.M., Silva, J.J.R., \& Del Vecchio, F.B. (2012). Relação entre força e agilidade avaliadas em jogadores de futsal. Revista Brasileira de Futsal e Futebol, 4: 77-86.

Priego Quesada, J.I., Olaso Melis, J., Llana Belloch, S., Pérez Soriano, P., González García, J.C., \& Sanchís Almenara, M. (2013). Padel: a quantitative study of the shots and movements in the high-performance. Journal of Human Sport $\mathcal{E}$ Exercise, 8(4): 925-931. doi: 10.4100/jhse.2013.84.04.

Sánchez-Alcaraz, B. (2014a). Análisis de la exigencia competitiva del pádel en jóvenes jugadores. Kronos, 13(1), available in: http://gse.com/es/journals/kronos/articulos/analisisde-la-exigencia-competitiva-del-padel-enjovenes-jugadores-1707 [2015 mai 20].

Sánchez-Alcaraz, B. (2014b). Diferencias em las acciones de juego y la estructura temporal en el pádel masculino y femenino de competición. Acción Motriz, 12(1): 17-22.

Sánchez-Alcaraz, B.J., \& Sánchez-Pay, A. (2010). Medición de la condición física del jugador de pádel a través de tests. Trances, 6: 45-62.

Shim, J., Carlton, L.G., Chow, J.W., \& Chae, W.S. (2005). The use of anticipatory visual cues by highly skilled tennis players. Journal of Motor Behavior, 37: 164-175. doi: 10.3200/JMBR.37.2.164-175.

Signorile, J.F., Sandler, D.J., Smith, W.N., Stoutenberg, M., \& Perry, A.C. (2005). Correlation analyses and regression modeling between isokinetic testing and on-court performance in competitive adolescent tennis players. Jounal of Strength $\mathcal{E}$ Conditioning Research, 19: 519-526. doi: 10.1519/R-15514.1.

Silva, C.D., Natali, A.J., Lima, J.R.P., Bara Filho, M.G., Garcia, E.S., \& Marins, J.C.B. (2011). Yo-Yo IR2 test e teste de margaria: validade, confiabilidade e obtenção da frequência cardíaca máxima em jogadores jovens de futebol. Revista Brasileira de Medicina do Esporte, 17: 344-349. doi: 10.1590/S1517-86922011000500010.

Silva, F.F., Penido, C.A., Junior, V.L., Souza, R.A., \& Villaverde, A.B. (2014). Correlação entre a dinamometria e teste funcional em atletas de handebol. Revista Brasileira de Medicina do Esporte, 20(3): $\quad 172-175$. doi: 10.1590/151786922014200301872.

Zanchet, M.A., \& Del Vecchio, F.B. (2013). Efeito da kinesiotaping sobre força máxima e resistência de força em padelistas. Fisioterapia e Movimento, 26: $115-121$. 